\title{
Clinical Usefulness of Urinary Growth Hormone Measurements in Normal and Short Children According to Different Expressions of Urinary Growth Hormone Data
}

\author{
M. L. GRANADA, A. SANMARTí, A. LUCAS, I. SALINAS, J. M. CUATRECASAS, M. FOZ,
} A. CARRASCOSA, AND L. AUDİ

Hormonal Laboratory [M.L.G., L.A.] and Endocrine Service [A.S., A.L., I.S., J.M.C., M.F.], Hospital Germans Trias-Pujol, and Pediatric Service, Hospital Materno-Infantil Vall d'Hebron [A.C.], Autonomous University of Barcelona, Barcelona, Spain

\begin{abstract}
To assess the clinical usefulness of urinary growth hormone (UGH) measurements, a UGH determination technique, including dialysis, ultrafiltration, and measurement by polyclonal-coated tube RIA, was established. Sixty-three short children were studied: 56 idiopathic growth retarded (37 prepubertal and 19 pubertal) and seven prepubertal with classic GH (growth hormone) deficiency. Forty-two healthy children ( 32 prepubertal and 10 pubertal) served as controls. Two groups of adults were studied: eight with active acromegaly and 11 healthy controls. UGH was measured in 24-h urine samples from all patients and controls. Mean \pm SD UGH excretion expressed as $\mathrm{ng} / 24 \mathrm{~h}$ was significantly lower in the $\mathrm{GH}$ deficient group compared with prepubertal growth-retarded and control children $(p<0.01)$. No differences were found between UGH excreted by controls and by the growth-retarded groups. Pubertal children excreted significantly higher amounts of GH when UGH was expressed as $\mathrm{ng} / 24 \mathrm{~h}(p<0.02$ and $p<0.03$, respectively), but this difference disappeared when UGH was expressed as $\mathrm{ng} / \mathrm{g}$ creatinine. UGH was significantly higher in acromegalic patients compared with adult controls $(p<0.001)$. Differences between day, night, and 24-h UGH were studied in 23 children. UGH in night urine was significantly lower whether expressed as the total amount or as ng/g creatinine. The effect of recombinant $h G H$ administration on UGH was studied in 13 children after 6 and 12 mo of treatment. UGH increased significantly under recombinant hGH treatment. An endogenous GH secretion study was performed in 41 children: UGH expressed as $\mathrm{ng} / 24 \mathrm{~h}$ correlated significantly with mean serum 24-h GH, IGF-I concentration, chronologic age, and growth velocity, whereas when expressed as ng/g creatinine, UGH correlated only with mean serum $24-\mathrm{h} \mathrm{GH}$ and growth velocity. In conclusion, UGH determination is a noninvasive, easily repeatable way of assessing GH secretion. UGH expressed as the total amount per $24 \mathrm{~h}$ would appear to be a more advantageous approach to the expression of UGH data for clinical purposes. (Pediatr Res 32: 73-76, 1992)
\end{abstract}

\section{Abbreviations}

GH, growth hormone

UGH, urinary growth hormone

Received February 10, 1991; accepted April 2, 1992.

Correspondence and reprint requests: M. L. Granada, Hormonal Laboratory, Hospital Germans Trias-Pujol, 08916 Barcelona, Spain.

Supported by Fondo de Investigaciones Sanitarias de la Seguridad Social (FISS 89-0541) and Kabi-Pharmacia (Peptide Hormones).
Cr, creatinine

IC-GH, mean serum 24-h GH

SDS, standard deviation score for height

r-hGH, recombinant human growth hormone

In recent years UGH determination has been proposed as an alternative way of estimating spontaneous $\mathrm{GH}$ production. However, the low concentration of $\mathrm{GH}$ in urine, far below the sensitivity of assays used for GH determination in serum, and the presence of interfering substances in normal urine make UGH determination difficult. Different strategies basically involving sample dialysis and concentration have been used to overcome these problems (1-6). Alternatively, ultrasensitive immunoassays, which at present are commercially unavailable (79), have been developed. Results vary according to the different techniques used for quantitation and the differences in protocols for sample collection and result expression.

We use a simple method in which UGH can be measured by a commercially available RIA after dialysis and one-step concentration $(5,10)$. To assess the most clinically useful expression of UGH data, UGH was measured as the total amount per collection period and as the concentration per $\mathrm{g}$ of $\mathrm{Cr}$. Differences among several groups (normal, GH-deficient, and growth-retarded children, normal adults, and acromegalic patients), the effect of $\mathrm{r}-\mathrm{hGH}$ treatment, and correlations with endogenous GH secretion and other parameters related to growth were studied.

\section{PATIENTS AND METHODS}

\section{PATIENTS}

Twenty-four-h Urine Studies. Control group. Forty-two healthy children [height $>10$ th percentile for age and sex according to Tanner's charts (11)] were classified into two subgroups: prepubertal ( 18 boys and 14 girls; age range 5.1 to 12.6 y; mean 8.9 y) and pubertal (Tanner stages 2-3: seven boys and three girls; age range 11.9 to $16.7 \mathrm{y}$; mean $13.5 \mathrm{y}$ ).

Idiopathic growth retardation. Fifty-six short but otherwise healthy children (height $<$ the 3rd percentile for age and sex and normal GH response to provocative stimuli) were divided into two subgroups: prepubertal ( 28 boys and nine girls; age range 4.2 to $14.4 \mathrm{y}$, mean $10.7 \mathrm{y}$; mean SDS for height -2.47 , range -3.7 to -2.0 ) and pubertal (Tanner stages 2-3: 13 boys and six girls; age range 10.8 to $16.7 \mathrm{y}$, mean age $14.0 \mathrm{y}$; mean SDS for height -2.5 , range -4.8 to -2.1 ). 
In addition, in 23 patients, 24 -h urine samples were collected as day and night urine. Night urine consisted of that produced during the sleep period and the first morning voiding. UGH was determined in day and night urine samples as well as in a $24-h$ sample consisting of a proportional mixture of the corresponding day and night volumes.

$G H$-deficient group. Seven prepubertal children (five boys, two girls) who met clinical criteria for $\mathrm{GH}$ deficiency and failed to respond to two different $\mathrm{GH}$ stimulation tests were included in this group.

Acromegaly group. Eight adult patients with active acromegaly and increased plasma IGF-I concentrations, increased baseline plasma GH levels that were not suppressed below $5 \mu \mathrm{g} / \mathrm{L}$ after an oral glucose load, and/or a paradoxical GH rise in response to thyrotropin-releasing hormone were included in this group.

Adult control group. Eleven healthy, nonobese adults (seven women, four men) aged between 28 and 45 y made up this group.

Recombinant hGH-treated group. In 13 prepubertal children (two GH deficient and 11 growth retarded) treated with $\mathrm{r}-\mathrm{hGH}$ $(0.5 \mathrm{IU} / \mathrm{kg} /$ wk divided into daily evening doses), UGH excretion was determined before the start of treatment and at 6 and 12 mo of $\mathrm{GH}$ therapy.

Endogenous GH Secretion Studies. Forty children [28 boys, 12 girls; 31 prepubertal, nine pubertal; mean chronologic age 11.8 y (range: $6.3-16.0$ y)] were studied. Five had normal growth, 31 had growth retardation, and four were diagnosed with $\mathrm{GH}$ deficiency; all underwent a 24-h integrated secretion study after their parents had given written informed consent. They were admitted the night before the study. The following morning, an indwelling nonthrombogenic catheter was placed in a forearm vein and blood collection tubes were replaced every $30 \mathrm{~min}$ during the next $24 \mathrm{~h}$ using a continuous withdrawal pump (Cormed Ambulatory Withdrawal System, model ML 6-5 H; Cormed Inc., Medina, NY). After serum separation, aliquots from the 30 -min samples were combined to produce 24 -h pools in which IC-GH was measured. Urine was collected during the same 24-h period.

\section{METHODS}

Collection, dialysis, and concentration of urine samples. Twenty-four-h urine samples were collected and kept at $4^{\circ} \mathrm{C}$ throughout the collection period. Total volume was recorded and $50 \mu \mathrm{L}$ of $100 \mathrm{~g} / \mathrm{L} \mathrm{BSA}$ were added to $50-\mathrm{mL}$ aliquots of each sample to reach a BSA concentration of $1 \mathrm{~g} / \mathrm{L}$. The urine was centrifuged to remove debris, and urinary $\mathrm{Cr}$ concentration was determined by reaction with picric acid in an automatic analyzer (Technicon RA-1000; Technicon Instruments Corp., Tarrytown, $\mathrm{NY}$ ). Urine aliquots were stored at $-20^{\circ} \mathrm{C}$ until assayed.

After thawing, urine was dialyzed (dialysis sacks, 250-7U; Sigma Diagnostics, St. Louis, MO) against $0.1 \mathrm{M}$ phosphate buffer, $\mathrm{pH} 7.4$, at $4^{\circ} \mathrm{C}$ for $48 \mathrm{~h}$. Dialyzed urine was concentrated by centrifugal ultrafiltration at $4^{\circ} \mathrm{C}, 2000 \times g$, using Centrifugal Ultrafree units UFC2 TGC 02 (Millipore Corp., Bedford, MA) equipped with a $10000-\mathrm{D}$ nominal molecular weight limit polysulfone membrane. These units permit 30 - to 60 -fold concentration of a starting volume of $18.5 \mathrm{~mL}$ in approximately $2 \mathrm{~h}$. The volume of ultrafiltered samples was measured and a concentration factor calculated for each sample.

GH RIA. GH measurements in serum and concentrated urine samples were performed in duplicate by a polyclonal-coated tube RIA (SF-20101; Spectria Farmos Diagnostica, Turku, Finland) using an anti-GH antiserum raised in rabbit (OH003) and calibrated against the WHO IRP $66 / 217$. Sensitivity of the RIA assay calculated at $2 \mathrm{SD}$ from zero $\mathrm{GH}$ concentration was 0.23 $\mu \mathrm{g} / \mathrm{L}$. Sensitivity for urine samples after concentration (50-fold) was $4.6 \mathrm{ng} / \mathrm{L}(0.46 \mathrm{pg} /$ tube). Intra- and interassay coefficients of variation were 8.4 and $14.5 \%$ at $1.5 \mu \mathrm{g} / \mathrm{L}$ and 3.9 and 6.6 at 15 $\mu \mathrm{g} / \mathrm{L}$, respectively. After dialysis and concentration, recovery of added $\mathrm{GH}$ (different amounts of $\mathrm{GH}$ were added to urine samples to obtain $\mathrm{GH}$ concentrations between 0.03 and $0.12 \mu \mathrm{g} / \mathrm{L}$ ) was $86.9 \%$ (range 79.8-103.8\%).

IGF-I was quantified by a double antibody disequilibrium RIA assay (Incstar Corp., Stillwater, MN) in serum samples after separation of IGF-I from binding proteins using octadecasilylsilica cartridges (C18 Sep-Pak; Waters Associates, Milford, MA).

Data analysis. UGH is expressed as $\mathrm{ng} / 24 \mathrm{~h}$ and as $\mathrm{ng} / \mathrm{g} \mathrm{Cr}$. Group data are expressed as mean \pm SD. The nonparametric Wilcoxon rank sum and Mann-Whitney U test were used to assess the significance of differences between groups. The relationship between UGH excretion and 24-h serum GH, IGF-I, chronologic age, SDS for height, and growth velocity were assessed by the parametric Pearson correlation test.

\section{RESULTS}

Comparison of UGH by groups. Mean \pm SD UGH excretion from the different groups, expressed as $\mathrm{ng} / 24 \mathrm{~h}$ and as $\mathrm{ng} / \mathrm{g} \mathrm{Cr}$, is shown in Table 1. GH-deficient children excreted significantly lower amounts of $\mathrm{GH}$ than prepubertal controls and growthretarded children $(p<0.01)$. No differences were found between UGH excreted by controls and the growth-retarded group (prepubertal versus prepubertal and pubertal versus pubertal). In both groups, pubertal children excreted significantly higher amounts of $\mathrm{GH}$ than prepubertal children when UGH was expressed as ng/ $24 \mathrm{~h}(p<0.02$ and $p<0.03$, respectively), but this difference disappeared when UGH was expressed as $\mathrm{ng} / \mathrm{g}$ $\mathrm{Cr}$. Control adults excreted significantly less UGH than pubertal children $(p<0.05)$ when UGH was expressed as ng/24 h and less than both prepubertal and pubertal children $(p<0.001)$ when UGH was expressed as $\mathrm{ng} / \mathrm{g}$. Cr. Twenty-four-h UGH excreted by acromegalic patients was significantly higher than that excreted by the adult control group $(p<0.001)$.

$U G H$ in 24-h, day, and night urine samples. Table 2 shows mean \pm SD of $24-h$, day, and night UGH values in 22 patients, expressed as ng/collection period and as ng/g Cr. Twenty-four-h UGH was also calculated as the sum of day and night results.

Table 1. Comparison of UGH by groups

\begin{tabular}{lcc}
\hline & $\begin{array}{c}\mathrm{ng} / 24 \mathrm{~h} \\
(\mathrm{mean} \pm \mathrm{SD})\end{array}$ & $\begin{array}{c}\mathrm{ng} / \mathrm{g} \mathrm{Cr} \\
(\mathrm{mean} \pm \mathrm{SD})\end{array}$ \\
\hline Prepubertal children & & \\
$\quad$ Controls $(n=32)$ & $15.5 \pm 11.1$ & $33.1 \pm 22.5$ \\
$\quad$ Idiopathic growth retardation $(n=37)$ & $12.5 \pm 8.4$ & $23.8 \pm 13.5$ \\
$\quad$ GH deficiency $(n=7)$ & $4.4 \pm 5.0^{*}$ & $7.8 \pm 8.3^{*}$ \\
Pubertal children & & \\
$\quad$ Controls $(n=10)$ & $31.6 \pm 19.2 \dagger$ & $48.0 \pm 27.0$ \\
$\quad$ Idiopathic growth retardation $(n=19)$ & $24.9 \pm 22.6 \neq$ & $31.0 \pm 20.1$ \\
Adults & & \\
$\quad$ Controls $(n=11)$ & $9.6 \pm 4.1 \S$ & $9.0 \pm 4.4 \|$ \\
$\quad$ Acromegaly $(n=8)$ & $330 \pm 362 \pi$ & $425 \pm 307 \uparrow$ \\
\hline
\end{tabular}

$* p<0.01$ vs prepubertal controls and idiopathic growth retardation.

$\dagger p<0.02$ vs prepubertal controls.

$\$ p<0.03$ vs prepubertal idiopathic growth retardation.

$\S p<0.05$ vs pubertal controls and growth-retarded children.

$\| p<0.001$ vs prepubertal and pubertal children.

If $p<0.001$ vs adult controls.

Table 2. GH excretion in 24-h, day, and night urine samples

\begin{tabular}{lcccccccc}
\hline & \multicolumn{3}{c}{ UGH (ng/collection period) } & & \multicolumn{3}{c}{ UGH (ng/g Cr) } \\
\cline { 2 - 4 } \cline { 7 - 9 } & $24 \mathrm{~h}$ & Day & Night & Day + night & & 24 h & Day & Night \\
\hline Mean $(n=22)$ & 25.7 & 13.6 & $10.2^{*}$ & 23.8 & & 38.8 & 36.7 & $30.1 \dagger \ddagger$ \\
SD & 17.2 & 10.1 & 8.1 & 15.7 & & 20.6 & 20.5 & 18.9 \\
\hline
\end{tabular}

$* p<0.04$ vs day.

$\dagger p<0.003$ vs $24 \mathrm{~h}$.

$\ddagger p<0.03$ vs day. 
Twenty-four-h UGH correlated significantly with day ( $p<$ $0.001)$ and night $(p<0.001) \mathrm{UGH}$ either expressed as ng/time or as ng/g Cr. When UGH was expressed as the amount of GH per period of time, no differences were found between 24-h and the sum of day and night, and night UGH was lower than day UGH $(p<0.04)$, although in an individual analysis eight of the 22 patients had night UGH excretion higher than day UGH excretion. When $\mathrm{UGH}$ was expressed as $\mathrm{ng} / \mathrm{g} \mathrm{Cr}$, night excretion was significantly lower than 24-h $(p<0.003)$ and day excretion $(p<0.03)$.

Effect of $r$-hGH treatment on $U G H$ excretion. UGH excretion (ng/24 h, mean $\pm \mathrm{SD}$ ) before treatment $(12.9 \pm 6.5)$ was significantly lower than at 6 mo $(34.0 \pm 16.7, p<0.003)$ and 12 mo $(38.9 \pm 14.2, p<0.002)$ of $\mathrm{r}-\mathrm{hGH}$ treatment. Similar differences were found between $\mathrm{GH}$ excretion $(\mathrm{ng} / \mathrm{g} \mathrm{Cr})$ before $(22.3 \pm 11.9)$ and after $6(48.5 \pm 21.5, p<0.003)$ and $12 \mathrm{mo}(47.8 \pm 10.9, p$ $<0.002$ ) of treatment. No differences were found between UGH excretions at 6 and 12 mo.

Relationship of $U G H$ to $I C-G H, I G F-I$, age, growth velocity, and SDS for height. Table 3 shows the mean \pm SD and range of age, SDS for height, growth velocity, serum IGF-I concentrations and IC-GH of the endogenous secretion study group. UGH excretion expressed as $\mathrm{ng} / 24 \mathrm{~h}$ correlated significantly with ICGH $(p<0.0001)$, baseline plasma IGF-I concentration $(p=$ $0.01)$, chronologic age $(p<0.02)$, and growth velocity $(p<$ $0.0001)$. UGH excretion expressed as $\mathrm{ng} / \mathrm{g} \mathrm{Cr}$ correlated significantly with IC-GH $(p<0.0001)$ and growth velocity $(p=0.001)$ but not with IGF-I or chronologic age. No correlation was found between UGH excretion and SDS for height.

\section{DISCUSSION}

Different methods $(1-10,12)$ have been used to measure UGH, which has been shown to reflect endogenous GH secretion $(5,6$, 12-18) and to enable detection of plasma GH concentration variations in response to provocative stimuli $(4,12,13,17,19$, 20 ) in individuals with preserved renal function. However, there is a lack of agreement in the literature as to which method is the best for collecting and expressing UGH data, because results of different collection periods (from minutes to $24 \mathrm{~h}$ ) expressed either as total UGH amounts per period, $\mathrm{Cr}$ excretion, body surface area, or weight have been reported.

In our series, UGH excretion (ng/24 h) clearly differed in some groups (GH-deficient versus prepubertal controls or idiopathic short children; prepubertal versus pubertal; ađult controls versus acromegalic patients), as already reported (3, 12, 14-18, 20-23). However, the increased $G H$ secretion in puberty $(24,25)$ reflected in UGH excretion $(12,15,17,22)$ disappeared when UGH was expressed as ng/g Cr. Previous reports have documented that $\mathrm{Cr}$ excretion varies as a function of body muscle mass (26); thus, to express UGH per $\mathrm{g}$ of $\mathrm{Cr}$ may result in falsely low UGH values in puberty, as has been suggested by others $(18,20)$.

Twenty-four-h endogenous GH secretion has been reported to correlate with other parameters related to growth, such as IGF-I (25), growth velocity (27), chronologic age (24), and SDS for height (28). Some authors have demonstrated correlations between UGH and IGF-I $(14,16)$ and UGH and growth velocity (15). In our endogenous GH secretion study group, which in-

Table 3. Clinical and biochemical data from endogenous $G H$ secretion study group

\begin{tabular}{lclc}
\hline & Mean & SD & Range \\
\hline Age (y) & 11.8 & 2.6 & $6.3-16.0$ \\
SDS for height & -2.20 & 0.93 & $-4.8-+0.3$ \\
Growth velocity (cm/y) & 4.9 & 1.3 & $2.9-9.3$ \\
IGF-I (IU/mL) & 0.84 & 0.34 & $0.3-1.87$ \\
IC-GH (mg/L) & 3.1 & 1.7 & $1.0-8.1$ \\
24-h UGH (ng/24 h) & 20.9 & 17.9 & $0.0-96.7$ \\
24-h UGH (ng/g Cr) & 32.5 & 19.7 & $0.0-74.8$ \\
\hline
\end{tabular}

cluded prepubertal and pubertal control, growth-retarded, and GH-deficient children, UGH (ng/24 h) correlated significantly with IC-GH, serum IGF-I concentration, chronologic age, and growth velocity. However, when UGH was expressed as ng/g Cr, correlations between UGH and serum IGF-I and chronologic age were lost and the statistical significance with growth velocity worsened. Our study shows that UGH expressed as $n g / 24 \mathrm{~h}$ correlates better with biologic and auxologic parameters than when expressed as ng/g Cr. SDS for height revealed no correlation with UGH in any case.

In our study, the total amount of UGH during the day was significantly higher than that during the night, but this was not constant in all children, as already reported by Girard et al. (8). Moreover, when UGH was expressed per $\mathrm{g}$ of $\mathrm{Cr}$, night UGH was significantly lower than 24 -h and day UGH. Although UGH in day and night urine correlated closely with 24-h UGH per period of time or per $\mathrm{g}$ of $\mathrm{Cr}$, as reported by Girard and FischerWasels (17), we believe that UGH expressed as $\mathrm{ng} / 24 \mathrm{~h}$ might be the best index of $\mathrm{GH}$ secretion and might avoid differences in interindividual day-to-night variations.

UGH in prepubertal children treated with $\mathrm{r}-\mathrm{hGH}$ significantly increased when expressed either as $\mathrm{ng} / 24 \mathrm{~h}$ or $\mathrm{ng} / \mathrm{g} \mathrm{Cr}$, as also reported by others $(3,6,17,21,29)$. UGH determination may permit assessment of the effect on endogenous GH secretion of any treatment capable of modifying it: an increase has been demonstrated under testosterone or estrogen treatment $(6,17)$, whereas no change could be observed during a clonidine treatment trial (10).

In conclusion, UGH determination is a noninvasive, easily repeatable way of assessing GH secretion. Expression of UGH per $\mathrm{g}$ of $\mathrm{Cr}$ avoids errors in urine collection and time control; however, because urinary $\mathrm{Cr}$ is not homogeneously excreted throughout the 24 -h period and varies according to age and body mass, when UGH was corrected per $\mathrm{g}$ of urinary $\mathrm{Cr}$ the increased GH secretion that occurs in puberty as well as the correlation with IGF-I and age were lost. Differences among children between day and night UGH have also been observed. Consequently, UGH expressed as the total amount per $24 \mathrm{~h}$ would appear to be a more advantageous approach to the expression of UGH data for clinical purposes.

Acknowledgments. The authors thank Christine O'Hara for reviewing the English manuscript, Pilar Ortiz and Ana Vega for their excellent technical assistance, and Izasa S.A. for the gift of additional anti-GH antibody $\mathrm{OH} 003$ from Farmos.

\section{REFERENCES}

1. Bala RM, Beck JC 1971 Human growth hormone in urine. J Clin Endocrinol 33:799-806

2. Hanssen KF 1972 Immunoreactive growth hormone in human urine. Acta Endocrinol 71:665-676

3. Albini CH, Quattrin T, Vandlen RL, MacGillivray MH 1988 Quantitation of urinary growth hormone in children with normal and abnormal growth. Pediatr Res 23:89-92

4. Evans AJ, Wood PJ 1989 Development of an assay for human growth hormone in urine using commercially available reagents. Ann Clin Biochem 26:357357

5. Granada ML, Sanmartí A, Lucas A, Salinas I, Cuatrecasas JM, Audi L 1989 Urinary growth hormone excretion in children with growth delay before and under treatment. Horm Res 31(suppl 1):26(abstr)

6. Weissberger AJ, Ho KY, Stuart MC 1989 Quantification of urinary growth hormone $(\mathrm{GH})$ excretion by centrifugal ultrafiltration and radioimmunoassay: appraisal of the relationship between $24 \mathrm{~h}$ urinary $\mathrm{GH}$ and mean 24 h serum $\mathrm{GH}$ levels in normal and abnormal states of $\mathrm{GH}$ secretion. Clin Endocrinol (Oxf) 30:687-698

7. Hashida S, Ishikawa E, Nakagama K, Ohtaki S, Icchioka T, Nakajima K 1985 Demonstration of human growth hormone in normal urine by a highly specific and sensitive sandwich enzyme immunoassay. Anal Lett 18:16231634

8. Girard J, Erb T, Pampalone A, Eberle AN, Baumann JB 1987 Growth hormone in urine: development of an ultrasensitive assay applicable to plasma and urine. Horm Res 28:71-80

9. Pan F, Stevenson JL, Donaldson DL, Levy J, Wiegmann T, Moore WV 1990 Correlation of urinary albumin and $\beta 2$-microglobulin and growth hormone 
excretion in patients with diabetes mellitus and short stature. $\mathbf{J}$ Clin Endocrinol Metab 71:611-617

10. Sanmartí A, Lucas A, Granada ML, Salinas I, Reverter JL, Cuatrecasas JM, Foz M, Audí L 1990 Effect of chronic clonidine treatment on urinary growth hormone excretion and linear growth in children with short stature. Horm Res 34:193-196

11. Tanner JM, Whitehouse RH 1982 Atlas of Children's Growth. Academic Press, London

12. Girard J, Celniker A, Price A, Tanaka T, Walker J, Welling K, AlbertssonWikland K 1990 Urinary measurements of growth hormone secretion. Acta Paediatr Scand [Suppl] 366:149-154

13. Okuno A, Yano K, Itoh Y, Hashida S, Ishikawa E, Mohri ZI, Murakami Y 1987 Urine growth hormone determinations compared with other methods in the assessment of growth hormone secretion. Acta Paediatr Scand [Suppl] 337:74-81

14. Sukegawa I, Hizuka N, Takano K, Asakawa K, Horikawa R, Hashida S, Ishikawa E, Mohri Zl, Murakami Y, Shizume K 1988 Urinary growth hormone $(\mathrm{GH})$ measurements are useful for evaluating endogenous $\mathrm{GH}$ secretion. J Clin Endocrinol Metab 66:1119-1123

15. Edge JA, Hourd P, Edwards R, Dunger DB 1989 Urinary growth hormone during puberty in normal and diabetic children. Clin Endocrinol (Oxf) 30:413-420

16. Tanaka T, Yoshizawa A, Miki Y, Ito I, Tanaka M, Tanae A, Yokoya S, Hibi I 1990 Clinical usefulness of urinary growth hormone measurement in short children. Acta Paediatr Scand [Suppl] 366:155-158

17. Girard J, Fischer-Wasels Th 1990 Measurement of urinary growth hormone. Horm Res 33(suppl 4):12-18

18. Albini CH, Sotos J, Sherman B, Johanson A, Celniker A, Hopwood N, Quattrin T, Mills BJ, MacGillivray MH 1991 Diagnostic significance of urinary growth hormone measurements in children with growth failure: correlation between serum and urine growth hormone. Pediatr Res 29:619-622

19. Hashida S, Ishikawa E, Kato Y, Imura H, Mohri Z, Murakami Y 1987 Human growth hormone (hGH) in urine and its correlation to serum hGH examined by a highly sensitive sandwich enzyme immunoassay. Clin Chim Acta 162:229-235

20. Walker JM, Wood PJ, Williamson S, Betts PR, Evans AJ 1990 Urinary growth hormone excretion as a screening test for growth hormone deficiency. Arch Dis Child 65:89-92

21. Kohno H, Murakami Y, Kodaira T 1990 Urinary growth hormone measurement using a highly sensitive sandwich enzyme immunoassay: diagnostic and therapeutic uses in patients with growth hormone deficiency. J Clin Endocrinol Metab 71:1496-1500

22. Price DA, Addison GM, Herbert ED 1990 Increase in urinary growth hormone excretion in puberty. Arch Dis Child 65:1203-1204

23. Granada ML, Sanmartí A, Lucas A, Salinas I, Cuatrecasas JM, Foz M, Carrascosa A, Audí L 1990 Urinary excretion of growth hormone in children with growth delay, before and during treatment. Acta Paediatr Scand [Suppl] 370:180(abstr)

24. Zadik Z, Chalew SA, McCarter RJ, Meistas Jr M, Kowarski AA 1985 The influence of age on the 24-hour integrated concentration of growth hormone in normal individuals. J Clin Endocrinol Metab 60:513-516

25. Martha PM, Rogol Jr AD, Veldhuis JD, Kerrigan JR, Goodman DW, Blizzard RM 1989 Alterations in the pulsatile properties of circulating growth hormone concentrations during puberty in boys. J Clin Endocrinol Metab 69:563-570

26. Forbes $\mathrm{G}$, Bruining $\mathrm{G} 1976$ Urinary creatinine excretion and lean body mass. Am J Clin Nutr 29:1359-1366

27. Hindmarsh P, Smith PJ, Brook CGD, Matthews DR 1987 The relationship between height velocity and growth hormone secretion in short prepubertal children. Clin Endocrinol (Oxf) 27:581-591

28. Albertsson-Wikland K, Rosberg S 1988 Analyses of 24-hour growth hormone profiles in children: relation to growth. J Clin Endocrinol Metab 67:493500

29. Hibi I, Tanaka T, Yano H, Umezawa S, Kagawa J, Tanae A, Ishikiwa E 1987 An attempt to assess the replacement dose of human growth hormone in the treatment of growth hormone deficient children. Acta Paediatr Scand [Suppl] 337:87-92 